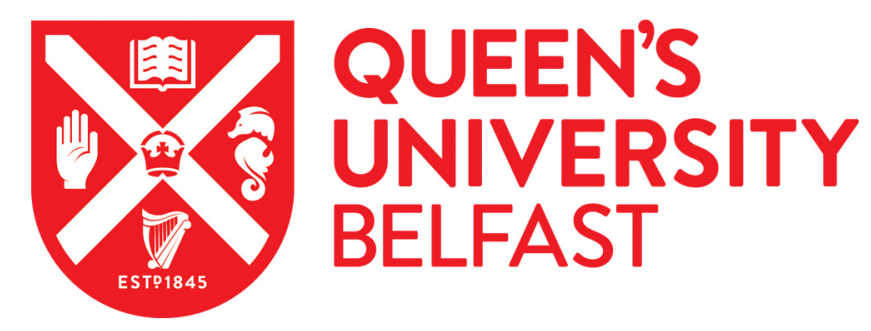

\title{
Citizenship and Structured Dependency: the implications of policy design for senior political power
}

Carney, G. M. (2010). Citizenship and Structured Dependency: the implications of policy design for senior political power. Ageing \& Society, 30(2), 229-251. https://doi.org/10.1017/S0144686X09990110

Published in:

Ageing \& Society

Document Version:

Peer reviewed version

Queen's University Belfast - Research Portal:

Link to publication record in Queen's University Belfast Research Portal

Publisher rights

(c) Cambridge University Press 2009

\section{General rights}

Copyright for the publications made accessible via the Queen's University Belfast Research Portal is retained by the author(s) and / or other copyright owners and it is a condition of accessing these publications that users recognise and abide by the legal requirements associated with these rights.

Take down policy

The Research Portal is Queen's institutional repository that provides access to Queen's research output. Every effort has been made to ensure that content in the Research Portal does not infringe any person's rights, or applicable UK laws. If you discover content in the Research Portal that you believe breaches copyright or violates any law, please contact openaccess@qub.ac.uk. 
Citizenship and structured dependency: the implications of policy design for senior political power

GEMMA M. CARNEY

Irish Centre for Social Gerontology

National University of Ireland Galway 


\begin{abstract}
This paper argues that the structured dependency thesis must be extended to incorporate political power. The paper outlines a political framework of analysis for identifying who gains and who loses from social policy. I argue that public policy for older people is a product, not only of social structures, but also of political decision-making. The Schneider and Ingram (1993) 'target populations' model is used to investigate how the social construction of groups as dependent equals lower levels of influence on policymaking. In United Kingdom and European research, older people are identified as politically quiescent. Conversely, seniors in the United States are viewed as one of the most politically influential and cohesive interest groups in American political culture. Why are American seniors perceived as politically powerful, while older people in Europe are viewed as dependent and politically weak? This paper applies the 'target populations' model to senior policy in the Republic of Ireland to investigate how US theoretical work may be used to identify the significance of senior power in policy development. I conclude that research must recognize the connection between power, politics and social construction to investigate how state policies can influence the likelihood of seniors to resist structured dependency using political means.
\end{abstract}

KEY WORDS - political economy, policy, structured dependency, political power, social construction.

\title{
Introduction
}

The purpose of this paper is to link the 'structured dependency' of older people (Townsend 1981) to the matter of their political participation. How does the experience of dependency in old age act as a cultural process, 'reflect(ing) back in the minds and expectations of citizens' (Baars et. al. 2006: 3)? The contrasting experiences of older citizens in Europe and the USA suggest that policies effect, not only socio-economic dependency, but also the capacity and potential of older people to mobilise as a cohesive interest group (Pierson 1993). Campbell's (2003) empirical work reveals that the US policy of universal benefits in old age through Social Security and Medicare contributed, not only to improving the welfare and independence of US seniors, but also to producing a cohesive and mobilised interest group, often referred to as 'senior power' (Turner, Shields and Sharp, 2001; Binstock in Hudson, 2005). Theoretical work undertaken by Schneider and Ingram (1993; 2005) identifies American seniors as an advantaged group for whom policy design reflects both positive social construction and high levels of political influence. American gerontologists are sceptical of the significance of senior power (Binstock 2000; Hudson, 2005), arguing that despite political activity, many older Americans become dependent by virtue of 'age relations - a system of inequality, based on age, which privileges the not-old at the expense of the old' (King and Calasanti in Baars 
et. al. 2006: 140). While dependency in old age might be a common experience on both sides of the Atlantic, the extent to which older people view dependency as a political issue differs. In a further empirical American study, Verba et. al. (1993: 310) find that recipients of non-means tested benefits, particularly Social Security and Medicare (namely, senior citizens), are more likely to be politically active than those receiving means tested benefits. American seniors' image as significant political actors contrasts sharply with UK and European research which finds older people to be disorganized politically, and consequently weak in terms influencing the policy agenda (Walker, 1999; Vincent, Patterson and Wale 2001). Likewise, public policy for older people is ad hoc and disjointed in many European countries. This anomaly in levels of political activity, on foot of policy feedback effects, is 'ripe for comparative research' (Pierson, 1993; Walker 2006a in Binstock and George 2006: 353). This paper aims to be the opening paragraph in a new chapter in empirical and theoretical research investigating citizenship and ageing in comparative national contexts.

The central focus of this paper is to investigate the extent to which the US research could be usefully applied to other western democratic states. The paper draws on the work of Walker (1981-2006), Townsend (1981; 2005), Estes (1979; 2001), Estes, Biggs and Phillipson (2003), Vincent, Patterson and Wale (2001) and Wilson (2000; 2005) linking the social construction of ageing to the invisibility and silence of older people in politics and policy-making. The paper is mindful of the complexity that globalisation has added to these debates (Estes, 2001). I apply the Schneider and Ingram (1993) 'target populations' model to the Irish experience of making policies for older people in a vacuum' (O'Shea in O'Dell, 2006). The paper concludes that policy design for older people has significant implications for their capacity to mobilise politically (Pierson 1993). In turn, the capacity of older people to mobilise as an age-based social or political 
movement has long-term implications for the quality of democratic citizenship enjoyed in old age. The relationship between citizenship and ageing will become increasingly important as populations age.

\section{Political economy of ageing and political power}

Early work in the political economy of ageing (Estes 1979; Walker1981; Townsend 1981) called for the conceptualisation of the dynamics of the ageing experience in terms of social structures rather than individual experiences (Estes 2001: 1; Bengston, Putney and Johnson in Johnson, 2000: 16). Since this work began (Estes 1979; Townsend 1981; Walker 1981) we have seen a re-modelling of that 'structured dependency' to fit the economically liberalised, culturally globalized and technologically dominated society of the twenty-first century (Baars et. al. 2006). The key variable that has not changed in the intervening period is the extent to which senior citizens have successfully mobilised as a movement for change. Civil and political institutions have not kept pace with demographic changes (Bengtson, Putney and Johnson 2000: 5; Simey in Bernard and Phillips, 1998: 254). At the same time, global discourse on ageing has tended to be conceived of in economic terms: what is the cost of disability, pensions or healthcare (King and Calasanti in Baars et. al. 2006: 139; Duncan 2008)? These questions reflect the globalised discourse of neo-liberalism (Walker 2006a), which prioritises economics in much policy planning in post-industrial societies. This work is highly influential, but omits the implications of ageing for democratic citizenship. A number of key questions must be asked if the political economy of ageing is to extend its impact as both a theoretical perspective and a lens through which the political and economic affects of ageing can be critically investigated. In democratic systems, citizenship rights are increasingly tied to economic agency (Verba, Schlozman and Brady 1995; Estes, Biggs and Phillipson 2003). In such a political climate, other than the vote, what means of 
influencing policy will be open to older people, who are traditionally excluded from the labour market? With increasing numbers of older people, will we see more specifically age-related policies designed? What will be the political impact of such policies? Whether future ageing policies produce structured dependency or promote independence depends on the extent to which seniors view their status as a common collective experience of ageing, or as a personal, individual experience resulting from bad luck or hard work earlier in the life course. Any citizen's perspective is attuned to national political culture, local social and political norms and direct experiences with policy. Therefore, the principles by which we choose to age at nation-state level will determine the shape of State policies. Will we choose to design policies in the liberal tradition of individualism and personal responsibility and reward, or with a view to sharing the dividends across generations, and collective risk pooling throughout the life course? Identifying which principles underlie national ageing policies is essential to understanding how policies create dependency, and whether that dependency can be resisted by political means.

Scholars of political economy argue that in recent years, the spread of neo-liberal costcutting plans has lead to the individualization of the social (Ferge, 1997), whereby states are expecting individuals and families to take responsibility for risks that were previously collectivized' (Walker 2006b: 66). Clearly, scholars recognise that cuts in public funding are the result of political processes at the governmental level, (i.e. the election of neoConservative political leaders in western democracies). Walker (2006a: 343) identifies "Thatcherism" and "Reagonomics" as influential in rolling back State policy in favour of free market alternatives. However, only a handful of researchers have begun to address how political means might be used to counter this pressure. Social policies are, first and foremost, the outcome of political decision-making. The disadvantage experienced by many older people as a result of the unequal distribution of social services and economic 
wealth stems from the fact that they are firstly deprived of power, respect, influence and basic human rights (Townsend 2006). While the UK literature has begun to recognise the significance of basic democratic principles of equality and human rights in influencing ageing policy (Duncan 2008: Townsend 2006), this work is still in its infancy. Meanwhile, researchers in the United States have made some progress in establishing why and how policies influence, not only socio-economic status (Estes, 1979; 2001; Estes, Biggs and Phillipson 2003), but also the capacity of certain groups to mobilise politically (Gaventa 1982: Campbell 2003: Schneider and Ingram 1993). 'If interest groups shape policies, policies also shape interest groups' (Pierson 1993: 598). By drawing on this work, this paper seeks to add to our theoretical understanding of how policy design might promote or inhibit the development of senior political action in future.

\section{US models of senior power}

American political scientists with an interest in democracy and policy design link political power and group identity with policy outcomes. 'Many scholars have delved into how policy creates politics’ (Lieberman, 1995: Schneider and Ingram 1991b; 1993; Pierson 1993). A policy of universal access to high quality education, health care or social security will obviously benefit all citizens. Where policies are designed for particular 'target populations,' group mobilisation around a common issue can result. Scholars will attest to 'seniors' in the US having higher social status and more political influence than their European counterparts, due to a combination of policy design and lobbying efforts (Estes, Biggs and Phillipson 2003: 135). American seniors benefit from a history of universal age-related benefits designed to counter the extreme poverty of seniors in the past. Age related benefits are sustained because of a positive social construction of seniors as 'deserving' in US political culture. Lieberman (1995) and Ingram and Schneider (1995) argue that 'the Social Security Act of 1935, which designed one kind of policy for the 
elderly and a very different kind for mothers of young children, actually contributed significantly to the current power of the retired persons' lobby' (Ingram and Schneider in Schneider and Ingram 2005: 25-26; Pierson 1993: 601). The 1935 Act means that senior citizens are unique in their right to Social Security and Medicare in the United States. Pierson (1993: 606) offers a number of examples of how welfare policies provide 'resources and incentives which can encourage individuals to act in ways that lock in a particular path of policy development.' Campbell (2003) also argues that Social Security provided seniors with the resources to increase their influence as citizens, and the universalism of benefits according to age produced a clear basis for communal identity. Campbell's (2003) comprehensive review of how seniors lobby to maintain Social Security, offers compelling evidence of how universal age-based policies can encourage political mobilisation for the target group. This large empirical study, based on the American Citizen Participation Study includes examples of the American Association of Retired Persons forcing Congress to make complete turnarounds on some policy proposals (Campbell 2003: 93). While some are sceptical of Campbell's methodology (Walker 2006a: 346), her central thesis, that 'policies make citizens,' (Campbell 2003) cannot be ignored. The implications of these findings for the structured dependency thesis are that different types of policy design will affect not only services for older people, and levels of welfare and independence amongst older cohorts, but also the likelihood that older people will mobilise collectively when those benefits come under threat. 'Both economic and political implications must be considered when designing social programs' (Campbell 2003; 146).

Schneider and Ingram's (1993) 'target populations' model also found American seniors to be a powerful and successful lobby. However, Schneider and Ingram (1993; 1997; 2005) adopt a more critical approach. They use the concepts of social construction and political 
power to build a model explaining how policy design can target groups in ways which convey powerful messages about who deserves government investment, and who does not. These messages affect group identity and levels of civic participation (Schneider and Ingram 2005: 19). Schneider and Ingram's (1993: 1997: 2005) work draws on a rich tradition of theorising around political power (Bachrach and Baratz 1962: Lukes 1974). This school of thought critiques pluralist notions of power for ignoring the capacity of dominant groups to control decision-making arena, referred to as the second and third dimensions of power. The result of second and third dimensional use of power is for dominant groups to succeed in silencing oppressed majorities who 'may be deprived even of the capacity to know their own interest' (Gaventa 1982 in Schneider and Ingram 1993: 8). Given the absence of theorising around political power in gerontology, this type of critical, theoretical work would be a welcome addition to our discipline. This work challenges us to identify, not only structural barriers to political mobilisation, but also less visible obstacles such as internalisation of experiences of dependency (Baars et. al. 2006). While seniors were not the central focus of Schneider and Ingram's (1993; 1997; 2005) theory, the model is useful as it can be applied to other western democratic political systems. In most cases, it is likely that very different 'target populations' would emerge. The main features of the model, and its implications for gerontological research, are outlined below.

\section{The 'target populations' model}

Schneider and Ingram (1993: 334) argue that 'target populations' are constructed differently in public discourse and policy design. Elected officials (members of political institutions who have been elected to office by democratic means) perceive certain groups as worthy of investment and this perception affects which policy tools are selected, and how policy choices are legitimated (Schneider and Ingram 1993: 339). 
Schneider and Ingram (1993: 335) define social constructions as 'stereotypes about particular groups of people that have been created by politics, culture, socialisation, history, the media, literature, religion...' Positive social constructions are 'deserving' or 'public-spirited' or 'intelligent' and negative constructions are 'stupid' or 'undeserving.' The model is developed specifically for American politics, identifying four different socially constructed target populations: advantaged (business, veterans, the elderly), contenders (the rich, big unions, minorities, cultural elites), dependents (women, children, disabled) and deviants (criminals, drug addicts, communists, gangs, flag burners). They summarise the model in the diagram below:

Figure 1: Social Constructions and Political Power: Types of Target Populations

\section{Constructions}

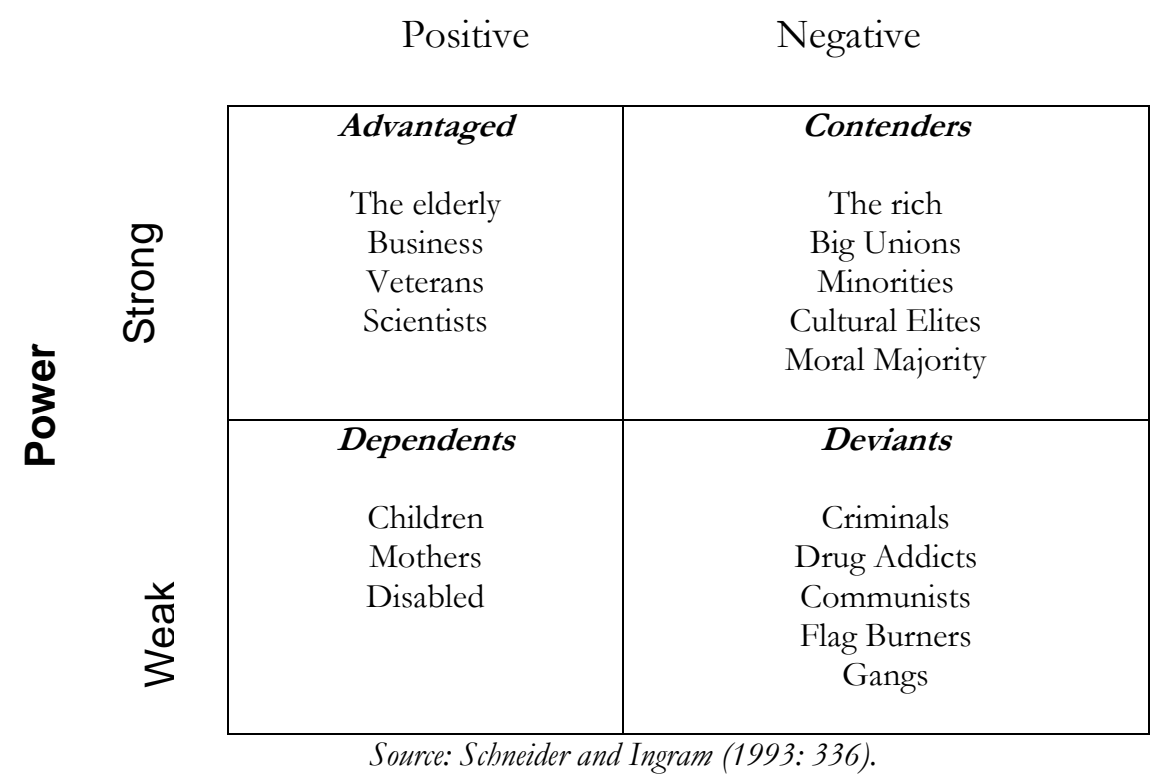

Groups who are politically powerful and positively constructed, (top left of Figure 1) are identified as 'advantaged.' Elected officials allocate resources to these groups, who are constructed as 'deserving and entitled,' with ease (Schneider and Ingram 2005). The advantaged are politically active, and elected officials know they will be supported at the polls and in other political fora for policy design favouring advantaged groups. The reverse is true for populations that are politically weak or negatively constructed as they 
hold neither electoral nor political influence (Schneider and Ingram 1993: 336). Deviants are the worst off in this category, as few people will support resource allocation towards criminals or drug addicts at the expense of groups perceived to be more 'deserving' and equally needy. Neither dependents nor deviants are politically mobilised. Elected officials can use stereotyped targeting to legitimately put the burden of policy on groups that are politically quiescent (Schneider and Ingram 1993: 337). In democratic systems, the electoral system provides a perpetual incentive for politicians to appeal to voters for reelection. The result is that elected officials are more sensitive to the demands of groups who they know to be politically engaged, and so are more likely to design generous and effective policies for them.

American seniors are widely recognised as politically active, though neither Binstock (2000) nor Campbell (2002) finds evidence that they vote strategically. Research does, however, note that a reputation for voting, when combined with advocacy and political action by lobby groups is enough to make elected officials sensitive to seniors' demands. The American Association of Retired People (AARP) and other Washington based lobbying organisations have been found to exert considerable influence on US political decision-making (Campbell 2003: Binstock in Hudson 2005: Duncan 2008). The implications of Schneider and Ingram's model for our understanding of senior power are twofold. Firstly, that a reputation for power is in itself a factor in maintaining power (Estes 2001). Even if senior power is a 'myth' (Walker 2006a), it is still necessary to acknowledge it, as a reputation for political action can influence policy design (Estes 2001; Campbell 2003). Secondly, that social constructions of 'deservingness' make it easier for public representatives to design beneficial policies for certain groups. In the American case, seniors reputation for political action, together with an identity constructed as deserving are enough to place seniors in an advantaged category in 
comparison with other social groups. However, in a time of economic retrenchment, 'deserving' groups will increasingly be constructed as 'costly burdens' (Walker 2006a). Recent partial privatization of Medicare (2003) leaves the traditional scheme vulnerable to future cuts, as competition is now in place. ${ }^{\mathrm{i}}$ In terms of the argument presented here, such piecemeal paring down of Medicare suggests that older American's status as deserving may be under threat (Walker 2006a; Herd and Kingson in Hudson 2005). The status of American seniors is being challenged in an ideological debate between neoConservative proponents of 'generational equity' and liberal supporters of 'generational interdependence' (Williamson and Watts-Roy in Hudson, 2008). The generational equity lobby implies that seniors are taking future resources from children and young families. This ideology, developed during the Reagan era, socially constructs American seniors as 'greedy geezers' and challenges the traditional perception of seniors as 'deserving' (Duncan 2008). It may be impossible to prove the degree to which Schneider and Ingram's classification as seniors as 'advantaged' truly reports the status of American seniors today. However, universal benefits for seniors have historically placed them ahead of other groups, and the generational equity lobby is arguably a form of 'backlash' (Wolf, 1991). Nevertheless, the fact that Social Security has survived repeated attempts to de-legitimate it as 'fiscal child abuse' (Duncan 2008: 1142) suggests it may indeed be 'locked in' to American political culture in terms of the incentives and resources it provides to seniors as an interest group (Pierson 1993: 608). The fact that the generational equity versus interdependence debate has developed, and an infrastructure of interest groups and advocacy organizations has developed around it, demonstrates that US political culture is ahead in acknowledging that demographic ageing has implications for democratic citizenship. Thus far the generational equity debate has had the upper hand in terms of influential media activity (Williamson and Watts-Roy in Hudson 2008: 15). 'Historically, except under very special circumstances such as the 
Great Depression, the counter theme of community obligation has been less powerful than the dominant theme (or value) of individualism' (Williamson and Watts-Roy in Hudson 2008: 15). Recent unprecedented loss of legitimacy in global capitalism, coupled with a strong message of social solidarity under the Obama administration suggests that generational interdependence may have more opportunity to gain credence in the immediate future.

Campbell (2003) and Schneider and Ingram's (1993) work presents challenges and opportunities for gerontologists. If American seniors have managed to maintain Social Security in a political culture whose philosophy of individualism and freedom from state interference is enshrined in policy and practice, that is significant. In Europe, social gerontology has inferred that old age is socially constructed as a time of dependency (Townsend 2006), and shown that older people are politically weak (Walker and Naegele, 1999: Vincent, Patterson and Wale 2001). However, we have not clearly linked political power and social construction to how policies for older people in Europe are designed (Schneider and Ingram 1993: 337). If we were to apply Schneider and Ingram's (1993) model to European States we could expect to find piecemeal, disjointed and ad hoc policies for older people at the national level. This proposition suggests that political power must become a more important variable in future European research in the political economy of ageing. To what extent is the absence of resources and incentives to take political action for European elders a result of unequal political systems, where some citizens' voices count for more than others (Verba, Schlozman and Brady 1995)? If political mobilisation around Social Security has resulted in seniors maintaining benefits in the American case, what potential is there for social movements having similar effects in other democratic states? As a first attempt at applying this model outside US political culture, the next section examines policy design for older people in Ireland, re- 
conceptualising Schneider and Ingram's (1993) model for Irish political culture. The Irish case study would seem to confer with Schneider and Ingram's contention that a neo-liberal state apparatus, when choosing to diminish the relationship between State and citizen welfare, can use the social construction of dependent groups to allocate resources in favour of more politically powerful groups.

\section{Policy design for older people in the Republic of Ireland}

Policy design for older people in Ireland tends to be ad hoc and concerned with minimal health outcomes. There are few universal age-related State benefits. Health care, pensions and long-term care are increasingly privatised in a political culture dominated by a long history of colonialism (1800-1921), followed by a period of clerical nationalism (1922-73) and more recently secularisation and economic liberalisation (1973-present). Long-term care funding, chiropody services, severely limited home care services and a cancer screening service that has an age barrier of 64 , have dominated the ageing policy debate over the past 10-15 years. ${ }^{\text {ii }}$ Over the past 20 years, the decline of the power and authority of the Catholic Church and associated institutions such as the extended family has left a 'policy vacuum' in relation to ageing (O’Shea in O'Dell 2006). Until joining the European Economic Community in 1973, care of children and older people was almost exclusively the responsibility of married women (Galligan 1998). The Church itself was a major provider of healthcare and education (Power 2009). Though public perception is that the State now provides services previously supplied by either the Church or by women in the home, this is only partially the case. Investment in social welfare in Ireland is, in fact, lower than elsewhere in the European Union, 'neo-liberal and residual: it relies heavily on means-tested payments and private insurance and there is low direct service provision' (Timonen, Convery and Cahill 2006: 15). There is no clear agreement between citizens and government as to who is responsible for eldercare, pension provision, healthcare or 
any of the major policy issues presenting for ageing populations. Instead, there exists a 'state of nature' where older people and their working families cope with expensive privatised health and elder care systems, which are inconsistently and/or partially subvented by State programmes.

Given these circumstances, it is not surprising that the possibility of growing demand for pensions, healthcare and social inclusion measures for older people is reflected in public concern regarding demographic 'time bombs' (National Council on Ageing and Older People 2005). Public perception reflects a social construction of older people as needy but helpless. Government are expected to pity older people who represent no threat to existing power structures other than by virtue of their rising number (National Council for Ageing and Older People, 2005). Table 1 below, summarises this argument with evidence from gerontological research in the Republic of Ireland (right hand column). Schneider and Ingram (1993: 338) outline a number of key identifiers of dependent groups, which are summarised in the left hand column of the table. 
Table 1: Classification of Older People in ROI as Dependent according to Target Populations model

\begin{tabular}{|c|c|}
\hline $\begin{array}{c}\text { Dependent Groups are } \\
\text { (Schneider and Ingram 1993: 338): }\end{array}$ & $\begin{array}{l}\text { Examples from Public Policy for Older People in } \\
\text { the Republic of Ireland }\end{array}$ \\
\hline $\begin{array}{c}\text { Dependents' issues are rarely of 'national } \\
\text { importance.' }\end{array}$ & $\begin{array}{l}\text { Policy-making for older people in the ROI is } \\
\text { piecemeal and ad hoc. Older people have been } \\
\text { waiting for a National Positive Ageing Strategy for } \\
\text { some years now (O'Shea, 2006: 4). }\end{array}$ \\
\hline $\begin{array}{l}\text { Symbolic policies allow political leaders to show } \\
\text { concern without actually investing in dependent } \\
\text { people. }\end{array}$ & $\begin{array}{l}\text { History of symbolic gestures and policy } \\
\text { announcements which later emerge as pilots or } \\
\text { local projects with little funding (e.g. home care } \\
\text { packages, Carney, 2007). } \\
\text { Large gaps between stated government policy and } \\
\text { actual policy outcomes (O'Shea, 2006). }\end{array}$ \\
\hline $\begin{array}{l}\text { Policies tend to be contracted out or left as the } \\
\text { responsibility of lower levels of government. }\end{array}$ & $\begin{array}{l}\text { Services for older people are administered by State } \\
\text { agencies such as the Health Service Executive. } \\
\text { Long-term care has been privatized. The number of } \\
\text { beds in private and voluntary nursing homes } \\
\text { increased from } 6932 \text { in } 1997 \text { to } 13178 \text { by the end of } \\
2003 \text { (Mangan, 2006: 8) reaching 18,883 by the end } \\
\text { of } 2007 \text { (Nursing Homes Ireland, 2007). }\end{array}$ \\
\hline $\begin{array}{l}\text { Dependents have little or no say in policy } \\
\text { design. }\end{array}$ & $\begin{array}{l}\text { A platform of older people' organisations and } \\
\text { geriatricans united to urge government to engage in } \\
\text { meaningful consultation with older people before } \\
\text { introducing a system of co-payment for long-term } \\
\text { care entitled 'The Fair Deal' (Donnellan, Irish Times, } \\
\text { November, 28, 2007). }\end{array}$ \\
\hline $\begin{array}{l}\text { People in these groups are seen as the } \\
\text { responsibility of family, charities, the Church or } \\
\text { the private sector. }\end{array}$ & $\begin{array}{l}\text { The question of whether Church, State, family, } \\
\text { individual, community or social partners is } \\
\text { responsible for creating an 'age-friendly society' is } \\
\text { undecided (National Council on Ageing and Older } \\
\text { People, 2005). } \\
\text { O'Shea (in O'Dell, 2006) argues that policy for } \\
\text { older people has been developed in a 'vacuum' } \\
\text { where families are left to fill the gap. }\end{array}$ \\
\hline
\end{tabular}

Adapted from Schneider and Ingram (1993: 338); Additional material from O'Shea 2006; O'Dell, 2006; National Council on Ageing and Older People 2005; Irish Times 2007; Mangan 2006

Research presented in Table 1 suggests a very different target population status for older people in Ireland, to Schneider and Ingram's (1993) classification of American seniors. Figure 2 re-conceptualises Schneider and Ingram's model for Irish political culture. 
Figure 2: Applying Schneider and Ingram's Model to the Irish Case

\section{Constructions}

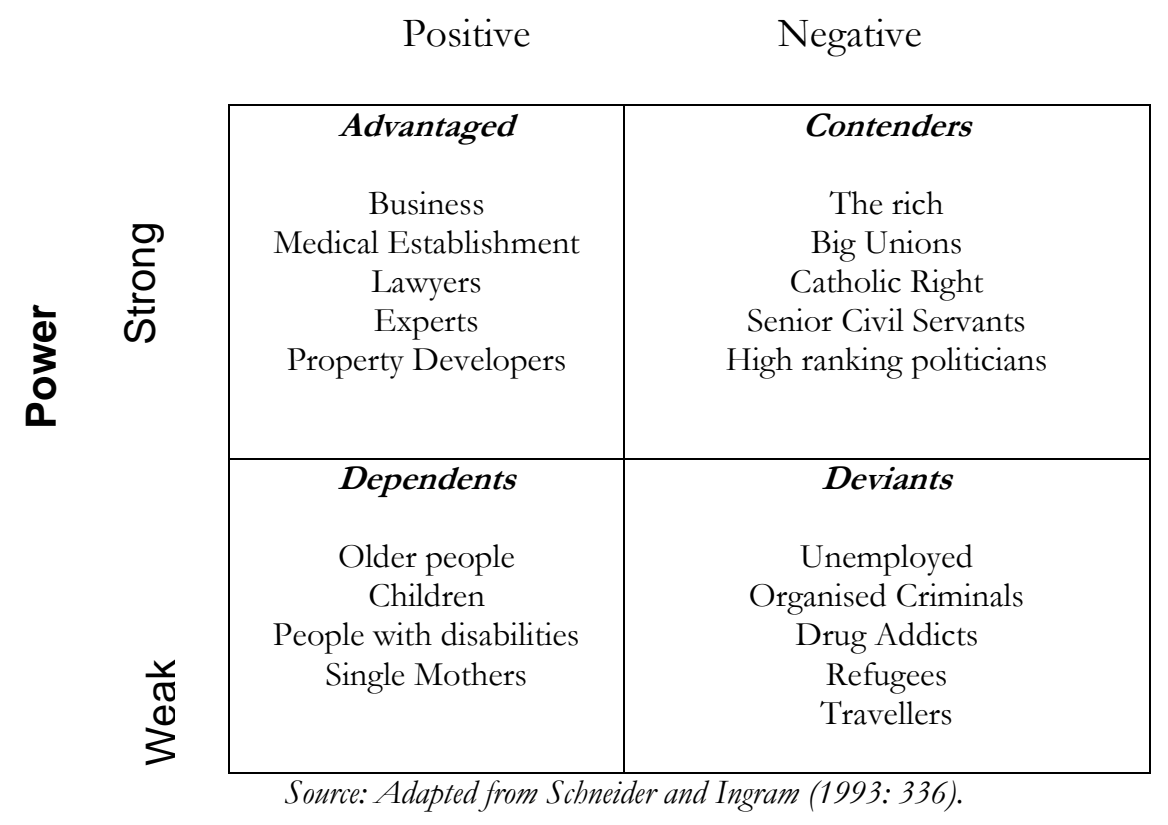

The status of older people in Ireland leaves them occupying the lower left hand quadrant of Figure 2 (positive social construction + weak political power $=$ dependent). This is significant given Schneider and Ingram's contention that: 'People's experiences with policies actually impact and help shape their identity, their orientation to government, their capacity for mobilization, their direct access to policy making and their understanding of what people "like me" can and should expect from government' (Schneider and Ingram 2005: 27). The fact that policy design is ad hoc and disjointed is reflected in how older citizens in Ireland seem to have internalised declining status in old age. The atomisation of older people as a group with a seemingly endless list of needs from chiropody, to transport, pension increases, long-term care and community services is perpetuated with equally interminable announcements of pilot schemes, local projects and incremental pension increases by government. During the economic boom (19942007), large government surpluses saw incremental increases in the State pension which 
reduced the number of older people at risk of poverty from 27.1per cent in 2004 to 20 per cent in 2005 at which it has stabilised (Central Statistics Office 2007: 27). From this analysis, I contend that older people in Ireland are 'dependent': perceived as needy and helpless, the responsibility of the private sector, politically passive and having low potential for mobilisation (Schneider and Ingram 1993: 341). Universalism, identified as key in the American case (Schneider and Ingram 2005), is the exception rather than the rule in terms of Irish social policy. The right of Irish citizens to State provided services is conditional on those services not costing too much. The lack of a rights based equality framework for older people suggests a weak and ineffectual older people's lobby. As the American case has shown, social movements play a crucial in allowing groups to improve their political, economic and social status (Campbell 2003; Estes, Biggs and Phillipson 2003). What is the role of interest groups in the Irish case?

\section{The role of interest groups}

The older people's lobby in Ireland is fragmented. There exist a relatively large number of advocacy and grassroots organisations of older people, who tend to take a fire-fighting approach, tackling problems as they arise. The large number of organisations means there are many voices competing to be heard, resulting in the presentation of the elder agenda as a set of disparate issues. These groups are beginning to adopt a more united approach under the 'Older and Bolder' banner, an alliance founded in 2006, but still embryonic in terms of developing a united and coherent political movement (www.olderandbolder.ie). Individual charities and grassroots organisations operate as separate entities, make individual submissions on important policy concerns and have fundamental political and policy disagreements. For instance, pensions and health policy are perpetually mentioned in annual submissions from age-related voluntary organisations to the Minister for Finance before budget day. Though groups may make similar claims to represent older 
people, they display little agreement on whether a system of social insurance, a better regulated private system or a state-funded benefit system for either pensions or healthcare is best. The lack of a shared set of principles bears testament to a broader public debate about whether $21^{\text {st }}$ century Irish political culture is closer to 'Boston or Berlin' (Kirby, Gibbons and Cronin 2002). The lack of a clear set of national principles on government's role in social policy-making, means that interest groups are unclear on what shape ageing policy design should take.

Operationally, voluntary organisations tend to specialise in particular roles, many providing services such as home help, advice and information, or arts programmes (Walsh and O'Shea 2008). In terms of political lobbying, groups engage with government to varying degrees. Some do this primarily through the media, while others use political contacts, direct letter writing or local lobbying of politicians. All of this work is commendable, but the lack of cohesion in the older people's lobby makes is easy for government to contract out key services to lower agencies, and to announce aggregate budgets for programmes and national projects which transpire to be local projects with little or no resources. The appointment of a junior Minister for Older People with a relatively small budget and no clear mandate ensures that the government appears to be 'doing something' for older people, while having little impact on existing power relations in Irish society. The aggregate result of a youthful and fragmented lobby is no clear improvement in the status of older people over the past 30 years, comparable with the transformation of the status of women (Galligan 1998), or modest but significant improvements in the relationship of other dependent groups (children and people with disabilities) to the State, during the same period. It is too soon to gauge the impact of the disability and children's rights legislation (Children Act 2001, Disability Act 2005), but certainly older people are at an earlier stage in working their way through the process of 
recognition and differentiation of their needs in terms of a rights based framework (Kitchin and Wilton 2003: 98). At this point in time it would seem that while all of these groups are dependent in the eyes of elected officials, the children's and disability movements are ahead in terms of developing counter arguments based on a rights framework of equality.

In terms of grassroots political action, there is evidence of Walker's (2006a: 350) 'barriers to political participation and influence' amongst older people in the Republic of Ireland. Older people struggle to develop a collective identity. Class divisions are reflected in voluntary organisations. More affluent 'Active Retired' organisations, whose ethos resonates with the popular culture of 'positive ageing' (McHugh 2004) are more vocal but tend not to take critical policy stances. For older people who have accumulated disadvantage the initiatives of charities and advocacy groups who speak for older people to government and State agencies tend to construct them as the deserving poor, ${ }^{\text {iii }}$ but leave no room for older people to speak for themselves (Evers and Wolf in Walker and Naegele, 1999: 44). The result is to 'depoliticise the situation of older people' whose situation is then viewed as a series of fragmented health, income, or mobility issues (Vincent, Patterson and Wale, 2001: 45). The pervasiveness of social constructions which use age to limit the influence and life expectations of older people institutionalize and normalise that fragmentation. The experience of grassroots political organisations with origins in the trade union movement such as the Irish Senior Citizens Parliament resonate with Vincent's $(2001 ; 82-101)$ conclusion regarding similar organisations in the UK. According to Vincent (2001), pensioners' organisations typically lack professionalism, are crowded out by charities who speak for older people, become internally divisive and adhere to national stances in the face of the unstoppable flow of global capitalism. These experiences reflect Walker's (2006a) second and third barriers to 
political influence, the fact that retirement provides less opportunity for collective identity formation and the lack of formal channels through which elders can exert political influence. Most older people do not seem to see their problems as soluble by political means. A political interpretation of their situation would see elders arguing that these disadvantages accumulate due to lack of access to power and resources. This level of political consciousness on the basis of age has yet to be observed. Claims are made on the basis of neediness and hardship rather than on the basis of robust engagement with government in the national interest (Schneider and Ingram 1993). However, protest marches and letter-writing from older people following October 2008 attempts by government to apply a means test to free primary medical care (referred to as the medical card) for the over 70s, suggest that removing existing universal benefits may provide a focus around which older people could unite and mobilise.

\section{Dependency in a time of financial crisis}

In part due to the global financial crisis, the Irish economy hit a sudden and severe downturn in Autumn 2008. The Irish government responded by announcing a number of cutbacks to benefits for dependent groups. Children were to be hit by increased class sizes at primary school level, fees for third level students were to be re-introduced and free universal primary medical care for the over 70 s was to be replaced with a means tested alternative. The result was protests by teachers and students' unions and older people's organisations; Age Action Ireland and the Irish Senior Citizens Parliament. Older people's organisations, supported by criticism of the plan from the influential Irish Medical Organisation (interest group representing general practitioners), organised two days of protest marches outside Dáil Éireann (the national parliament). Older people appeared on national news broadcasts, presenting an angry and united front in face of a threat to one of the few universal State benefits they receive. Within a week, the 
government had made an almost complete u-turn ensuring that only $5 \%$ of older people would fail to qualify for free medical care under the new means test. While the universalism of the medical card was lost, threats to never again vote for party in government may have been enough to shift older people's orientation from 'passive' to 'vigilant' in the perception of elected officials (Schneider and Ingram, 1993). This example demonstrates two key points. Firstly, the protests show how groups will mobilise when a universal entitlement is threatened, and particularly when a dependent group is supported by an advantaged group (in this case the GPs who enjoyed a generous allowance from government for elderly patients). Secondly, Schneider and Ingram's (1993; 2005) model suggests that if the current financial crisis leads governments to redesign policies, we may begin to observe how this changes the orientation of existing target populations towards government. Although the medical card for the over 70 s had been introduced only a few years previously, it quickly became widely supported; viewed as a right of those who had paid tax and social insurance throughout their working lives. In this case, the government had difficulty removing a universal benefit as the policy had become 'locked in' (Pierson 1993) to the local political culture. Moreover, we see an interaction between resource effects and universalism in that older people used one universal age related benefit (free travel on public transport), to travel to Dublin to protest at the removal of another universal benefit, free primary medical care. Possible inter-relationships between universal policy provision and accumulation of participatory resources (Verba, Schlozman and Brady 1995) must be further investigated.

\section{Summarizing the Irish Case}

Schneider and Ingram's ‘target populations' model offers some insight into why older people's policy design appears disjointed, illogical or ad hoc in the Irish case. By linking the dependent status of older people to their lack of political power, the multi- 
dimensional model allows us to begin to understand how a complex set of political interests and social processes conspire to produce 'structured dependency' in old age. The model also demonstrates why older people may encounter barriers to gaining political influence. Perhaps most significantly, the application of the Schneider and Ingram $(1993 ; 1997 ; 2005)$ model to the Irish case reveals how taking a holistic perspective on the position of older people vis à vis other socially constructed populations puts their disadvantaged status in perspective, suggesting that the success of politically powerful groups may be at the cost of weaker populations. It is arguable that older people in Ireland suffer resource effects from their dependency on paltry pensions (about $33 \%$ of Gross Average Industrial Earnings in 2007) which are difficult to augment given that their age bars them from the labour market. When combined with the vicissitudes of biological ageing, the affect is to make political action a luxury many feel they cannot afford. Conversely, the perception of American seniors as powerful suggests that political action may be a route to the process of identity formation identified in the social construction of seniors in the US where: 'the old become the aged become the elderly become senior citizens' (Campbell 2003; 65). What useful learning can be drawn from this comparison of Irish and US senior power and policy research for our understanding of citizenship and dependency in old age?

\section{Conclusion: citizenship and structured dependency}

Firstly, this analysis of Irish policy design and American senior power models suggests that there may be policy-feedback affects which impact on older people's capacity and potential to mobilize politically (Pierson 1993). Campbell (2003: 56) argues that universal Social Security provided older Americans with enough income and independence to become more like wealthy, educated Americans in terms of political participation and mobilization. If this is the case, the effect of policy design on senior politics must be 
investigated in other national contexts. In the Irish case, policy design for older people is based on minimising costs, so that the burden of ageing is placed on individual older people, a typical orientation by decision-makers towards dependent groups (Schneider and Ingram, 1993: 338), and a common trend in neo-liberal, globally competitive economies (Walker, 2006b). This process of policy-making is detrimental for democracy as it perpetuates class and income inequalities through the constant advantaging of the politically powerful and disadvantaging of the politically quiescent (Schneider and Ingram, 1997). However, while social constructions of older people as dependent may take a long time to change, the possibility of increasing senior political influence, or at least the reputation of seniors for taking political action, may hold more immediate promise. In particular, adding accumulation of participatory resources (Verba, Schlozman and Brady 1995: 514) to life course research would greatly enhance our knowledge of accumulated dis/advantage (Dannefer 2003). Also, work comparing the role of political culture, perhaps through the use of historical institutional analyses of different national contexts, in promoting or curtailing the development of age-based political movements, would be very welcome (Pierson 1993: 609-10).This leads to a second important implication of this research.

The comparative theoretical work identified here suggests that a reputation for political power has been shown to be almost as significant as real political action (Estes 2001: Binstock 2000: Campbell 2003). If reputation for political action spurs elected officials to produce policies that benefit target populations, then it is important to make it a concern of our research into public policy and ageing. If exercising political power does offer a potential means for older people to lift themselves out of 'structured dependency,' all the more reason to include all types of senior political power in our research. As Estes argues '...if people believe that something is so (e.g. that the elderly have political power), it 
becomes so through a form of self-fulfilling prophecy' (Estes, Biggs and Phillipson 2003; 129). The perception that seniors vote strategically makes politicians more sensitive to their demands as a politically mobilised group (Wilson, 2000: Turner, Shields and Sharp 2001). Reporting of senior political action must, therefore, be aware of this role for reputation. This role of reputation would be a fruitful line of enquiry for those aiming to re-classify older people as a potential source of social capital rather than a societal burden (Gray, 2009).

The findings presented here, added to the presentation of a fragmented lobby and disjointed policy design for older people in the Republic of Ireland, suggests that further comparative research is necessary to identify possible impacts of ageing for democratic citizenship in other nation-states. Cross-national comparison of barriers to politicisation is long overdue (Turner, Shields and Sharp 2001: 816). Empirical and theoretical extensions of the work presented here, as well as applications of other models of democratic participation (Verba, Schlozman and Nie, 1995); social capital (Putman, 1995) and age as a variable in electoral studies (Campbell, 2003) in national contexts beyond the United States would also add greatly to our understanding of citizenship and structured dependency.

Thirdly, the argument presented in this paper demonstrates a need for more critical, theoretical research, if we are to avoid contributing to the 'de-politicisation of older people' (Vincent, Wale and Patterson 2001). If lost opportunities for political engagement are to be understood as more complex than merely a failure to mobilize on the part of older people, the epistemology of ageing (Bengston, Putney and Johnson in Johnson 2000: 8) must link ageing to critical concepts like biological determinism, ${ }^{\text {iv }}$ and three dimensional conceptions of power and citizenship (Lukes 1974). To clarify, public 
discussion of ageing and older people tends to view older people as a passive, economically redundant or socially homogenous group. Like the 'biological determinism' so deplored by feminists of the 1970s (Jaggar 1973) which associated femininity with weakness, passivity and powerlessness, the frailties associated with advancing age have become a means of constructing the social status of retired and older people as passive consumers of welfare policies. Chronological age is then socially constructed to give it weight in terms of how we justify the allocation of power, resources and public investment away from older people (Estes 1979; Estes, Biggs and Phillipson 2003). When such stereotyping is accompanied by the commonplace disadvantage of growing older such as distance from the labour market, decrease in independent income and failing health, the effect can be devastating for the individual. Where populations are ageing, the possibility arises of an increasingly large cohort of people who are outside the workforce, are likely to encounter health problems, and experience social isolation and exclusion. If we find older people to be politically quiescent, a critical epistemology of ageing is necessary to understand, not only why the masses do not mobilize (Kelly 1998), but also to highlight the significance of the actions of those few radical individuals who do. By espousing such a critically engaged literature social gerontology would contribute to the development of a politically cognisant discourse, capable of resisting everyday ageism through the representation of older people as senior citizens in the language we use and the research we publish.

Finally, given that the political economy of ageing has already identified how policies create socio-economic 'structured dependency' (Townsend 1981), it seems timely to question whether such policies also produce 'political quiescence' (Gaventa 1982). This paper has sought to highlight how directly addressing the 'political' element of the political economy of ageing offers opportunities to address 'the general inadequacies of 
theory building within gerontology' (Baars et. al. 2006: 1). By applying the 'target populations' model to the Republic of Ireland, the paper sought to open a new chapter in 'comparative research on the multi-layered politics of aging' (Walker 2006a: 356). It is hoped that future national and comparative studies will produce a body of theoretical and empirical work identifying the implications of demographic ageing for democratic citizenship. Embracing comparative and inter-disciplinary research of this kind is essential if the political economy of ageing is to develop as a site for critical, relevant and emancipatory knowledge of ageing societies.

\section{Acknowledgments}

Thanks are due to Prof. Eamon O’Shea, Áine Ní Léime, Patricia Conboy, Dr. Nalini Persram, Prof. Andrea Louise Campbell, Neil Briscoe, Michael Carney Snr. and two anonymous reviewers whose comments immeasurably improved this paper.

\section{References}

Baars, J., Dannefer, D., Phillipson, C. and Walker, A. (2006) Aging, Globalization and Inequality: the new critical gerontology Austin: Baywood Publishing Company.

Bachrach, P and Baratz, M. S. (1962) 'Two faces of power' American Political Science Review 56, 4, 947-952.

Bengston, V. L., Putney, N. and Johnson, M. (2000) ‘The problem of theory in gerontology today' in Johnson, M. (ed.) The Cambridge Handbook of Age and Ageing Cambridge University Press.

Binstock, R. H. (2005) 'The contemporary politics of old age policies' in Hudson, R. B. (ed.) The New Politics of Old Age Policy Baltimore: John Hopkins. 2005.

Campbell A. L. (2003) How Policies Make Citizens: Senior Political Activism and the American welfare state New Jersey: Princeton University Press.

Central Statistics Office (2007) Ageing in Ireland Available on-line at: http://www.cso.ie/releasespublications/documents/other releases/2007/ageinginireland.pdf [Accessed October 18 2008]. 
Dannefer, D. (2003) 'Cumulative advantage/disadvantage and the life course: cross fertilizing age and social science theory' Journal of Gerontology: Social Sciences 2003 Vol. 58B, No. 6., S327-337.

Duncan, C. (2008) 'The dangers and limitations of equality agendas as means for tackling old-age prejudice' Ageing and Society, 28, 2008, 1133-1158.

Estes C. and associates (1979) The Aging Enterprise: a Critical Examination of Social Policies and Services for the Aged San Francisco: Jossey-Bass.

Estes C., Biggs, S. and Phillipson, C. (eds.) Social Theory, Social Policy and Ageing: a Critical Introduction Maidenhead: Open University, 2003.

Estes C. (2001) Social Policy and Ageing: a Critical Perspective Thousand Oaks: SAGE.

Galligan, Y. (1998) Women and Politics in Contemporary Ireland: from the Margins to the Mainstream London: Pinter.

Gray, A. (2009) 'The Social Capital of Older People’ Ageing and Society 29, 2009, 5-31.

Herd, P. and Kingson, E. R. (2005) 'Reframing social security: cures worse than the disease' in Hudson, R. B. (ed.) The New Politics of Old Age Policy Baltimore: John Hopkins. 2005

Hudson, R. B. (ed.) The New Politics of Old Age Policy Baltimore: John Hopkins. 2005

Jagger, A. (1977) 'Political philosophies of women's liberation' in Vetterling-Braggin, M., Elliston, F. A. and English, J. (eds.) Feminism and Philosophy New Jersey: Littlefield, Adams \& Co.

Kelly, J. (1998) Retbinking Industrial Relations: Mobilisation, Collectivism and Long Waves London: Routledge.

King, N. and Calasanti, T. (2006) 'Empowering the old: critical gerontology and anti-aging in a global context' in Baars, J., Dannefer, D., Phillipson, C. and Walker, A. (2006) Aging, Globalization and Inequality: the new critical gerontology Austin: Baywood Publishing Company.

Kirby, P., Gibbons, L. and Cronin, M. (eds.) Reinventing Ireland: Culture, Society and the Global Economy London: Pluto Press, 2002.

Kitchin, R. and Wilton, R. (2003) 'Disability activism and the politics of scale' The Canadian Geographer 47, no. 2, (2003) 97-115.

McHugh, K. (2003) 'Three faces of ageism: society, image and place' Ageing and Society, 23, 2003, 165-185.

Lukes, S. (2005). Power: A Radical View, second edition. Basingstoke: Palgrave Macmillan.

Minkler, M. and Estes C. L. (eds.) Critical Perspectives on Ageing: the Political and Moral Economy of Growing Old New York: Baywood, 1991

National Council on Ageing and Older people (2005) An Age-friendly Society: a position statement Report No. 88, Dublin: Stationary Office. 
O’Shea, E. (2005) 'Developing a healthy ageing policy for Ireland: the view from below' Health Policy Vol.

76, Issue 1, March 2006, pages 93-105.

O’Shea, E. (2006) 'Older and Bolder: towards a national strategy for older people’ at http://www.olderandbolder.ie downloaded Oct 22, 2008.

O’Shea, E. (2006) 'Public policy for dependent older people in Ireland: review and reform’ in O’Dell (ed.) Older people in Modern Ireland: essays on law and policy Dublin: First Law.

Pierson, P. (1993) 'Review. When effect becomes cause: policy feedback and political change' World Politics Vol. 45., No. 4 (Jul, 1993), pp. 595-628.

Pierson, P. (2000) 'Increasing returns, path dependence and the study of politics' American Political Science Review Vol. 94, No. 2 (Jun 2000), pp. 251-267.

Power, A. (2009) 'Spatial perspectives on voluntarism in learning disability services in Ireland' Journal of Social Policy 38, 2, pp. 299-315.

Putnam, R. (1995) Bowling Alone: the Collapse and Revival of American Community NY: Simon and Schuster

Schneider A. and Ingram H. (1993) "The social construction of target populations: implications for politics and policy," American Political Science Review 87 [June 1993]: 334-47

Schneider A. and Ingram H. (eds.) Deserving and Entitled: Social Constructions and Public Policy New York: SUNY Press, 2005.

Schneider A. and Ingram H. (1997) Policy Design for Democracy Kansas: University Press of Kansas.

Townsend P. (1981) 'The structured dependency of the elderly: a creation of social policy in the twentieth century' Ageing and Society, 1981, 1, 6-28.

Townsend P. (2006) 'Policies for the aged in the $21^{\text {st }}$ century: more 'structured dependency' or the realization of human rights?' Ageing and Society, 26, 2006, 161-179.

Timonen, V., Convery, J. and Cahill, S. (2006) 'Care revolutions in the making? a comparison of cash-forcare programmes in four European countries'Ageing and Society 26, 2006, 455-474.

Turner, M. J., Shields, T. G. and Sharp, D. (2001) 'Changes and continuities in the determinants of older adults' voter turnout 1952-1996' The Gerontologist, 41, 6, 805-818.

Verba, S., Schlozman, K. L., Brady, H. and Nie, N. H. (1993) 'Who participates? What do they say?' American Political Science Review 87, 2, 303-318.

Verba, S., Schlozman, K. L., Brady, H. (1995) Voice and Equality: civic voluntarism in American Politics Cambridge: Harvard University Press. 
Vincent, J. A., Patterson, G. and Wale K. (2001) Politics and Old Age: older citizens and political processes in Britain Aldershot: Ashgate.

Vincent, J. A. (1999) Politics, Power and Old Age Buckingham: Open University

Walker, A. and Naegele, G. (eds.) The Politics of Old Age in Europe Cambridge: Open University Press.

Walker, A. (1981) 'Towards a political economy of old age' Ageing and Society, 1981, 1, 73-94.

Walker, A. (2005) 'Towards an international political economy of ageing", 25 ${ }^{\text {th }}$ Volume celebration article, Ageing and Society, 25, 2005, 815-839.

Walker, A. (2006b) 'Reexamining the political economy of aging: understanding the structure/agency tension' in Baars, J., Dannefer, D., Phillipson, C. and Walker, A. (2006) Aging, Globalization and Inequality: the new critical gerontology Austin: Baywood Publishing Company.

Walker, A. (2006a) 'Ageing and politics: an international perspective' in Binstock, R. H. and George, L. L. (eds.) Handbook of Ageing and the Social Sciences London: Academic Press, $6^{\text {th }}$ edition.

Walsh, K. and O'Shea, E. (2008) Responding to Rural Social Care Needs: Older People Empowering Themselves, Others and Their Community. Health and Place Vol. 14; 795-803.

Williamson, J. and Watt-Roy, D. (2008) 'Aging boomers, generational equity, and framing the debate over social security' in Hudson, R. (ed.) Boomer bust: economic and political issues of the graying society (Two Volumes). Westport, CT: Greenwood Publishing Group. Available on-line at: http://www2.bc.edu/ jbw/documents/GEJWDW.pdf [accessed March 31st 2009]

Wilson, G. (2000) Understanding Old Age: Crritical and Global Perspectives. London:SAGE

Wilson, G. (2002) 'Globalisation and older people: effects of markets and migration' Ageing and Society, 22, 2002, 647-663.

Wolf, N. (1990) The Beauty Myth: how Images of Beauty are Used Against Women NY: Morrow.

Address for correspondence:

Dr. Gemma Carney, Researcher, Irish Centre for Social Gerontology, J.E. Cairnes

Building, National University of Ireland Galway, Republic of Ireland

E-mail: gemma.carney@,nuigalway.ie 
${ }^{\mathrm{i}}$ Sincere thanks are due to Andrea Louise Campbell for clarifying this point.

${ }^{\text {ii }}$ See O'Dell (ed.) Older People in Modern Ireland: essays in law and policy for detailed assessments on long-term care, health and social care more generally and the rights of older people in residential homes.

iii For example: 'Age Action Warns Older People in Wake of Attack' 28/02/2008 at http://www.ageaction.ie/news/article-28-02-

08.asp and 'Medical cards for the over 70s - must stay free' Herald $A M$ at http://www.herald.ie/national-news/medical-cards-forthe-over70s-must-stay-free-1490125.html both downloaded 15 October 2008.

${ }^{i v}$ Biological determinism refers to the association of certain biological characteristics with particular capabilities, so being female and passive, or old and forgetful. An example is the Darwinian conclusion that 'Man is more courageous, pugnacious and energetic than woman, and has more inventive genius' (Darwin quoted in Wetterling-Braggen et. al., 1977). Biologically determined conceptions of older people view them as universally forgetful, awkward or more likely to be interested in ageappropriate activities like knitting and gardening (ageist and gendered) than younger people. An example in contemporary culture is the 2008 cereal advertisement which claims that 'Shreddies' are 'knitted by Nans.' 